\title{
Effect of Double Bond Position on 2-Phenyl-benzofuran Antioxidants: A Comparative Study of Moracin C and Iso-Moracin C
}

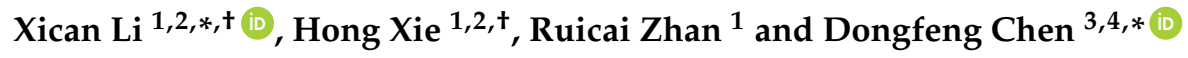 \\ 1 School of Chinese Herbal Medicine, Guangzhou University of Chinese Medicine, \\ Waihuan East Road No. 232, Guangzhou Higher Education Mega Center, Guangzhou 510006, China; \\ xiehongxh1@163.com (H.X.); michael_zcx@hotmail.com (R.Z.) \\ 2 Innovative Research \& Development Laboratory of TCM, Guangzhou University of Chinese Medicine, \\ Waihuan East Road No. 232, Guangzhou Higher Education Mega Center, Guangzhou 510006, China \\ 3 School of Basic Medical Science, Guangzhou University of Chinese Medicine, Waihuan East Road No. 232, \\ Guangzhou Higher Education Mega Center, Guangzhou 510006, China \\ 4 The Research Center of Basic Integrative Medicine, Guangzhou University of Chinese Medicine, \\ Waihuan East Road No. 232, Guangzhou Higher Education Mega Center, Guangzhou 510006, China \\ * Correspondence: lixican@126.com or lixc@gzucm.edu.cn (X.L.); chen888@gzucm.edu.cn (D.C.); \\ Tel.: +86-203-935-8076 (X.L.) \\ + These authors contributed equally to this work.
}

Received: 9 February 2018; Accepted: 22 March 2018; Published: 24 March 2018

\begin{abstract}
Two 2-phenyl-benzofurans, moracin C 2-[3', $5^{\prime}$-dihydroxy-4'-(3-methlbut-2-enyl)phenyl]6-hydroxybenzofuran and its isomer iso-moracin $C\left\{2-\left[3^{\prime}, 5^{\prime}\right.\right.$-dihydroxy-4'-(3-methlbut-1-enyl)phenyl]-6 -hydroxybenzofuran\}, were comparatively studied using redox-related antioxidant assays and non-redox antioxidant assays. Moracin $\mathrm{C}$ always resulted in higher $\mathrm{IC}_{50}$ values than iso-moracin $\mathrm{C}$ in the redox-related antioxidant assays, including $\bullet \mathrm{O}_{2}{ }^{-}$-inhibition, $\mathrm{Cu}^{2+}$-reducing power, $\mathrm{DPPH} \bullet$-inhibition, and $\mathrm{ABTS}^{+} \bullet$-inhibition assays. In the non-redox antioxidant assay, moracin $\mathrm{C}$ and iso-moracin $\mathrm{C}$ underwent similar radical-adduct-formation (RAF), evidenced by the peaks at $m / z 704$ and $m / z 618$ in HPLC-MS spectra. In conclusion, both moracin $C$ and iso-moracin $C$ can act as 2-phenyl-benzofuran antioxidants; their antioxidant mechanisms may include redox-related ET and $\mathrm{H}^{+}$-transfer, and non-redox RAF. A double bond at the conjugation position can enhance the redox-related antioxidant potential, but hardly affects the RAF potential.
\end{abstract}

Keywords: 2-phenyl-benzofuran; antioxidant; moracin; double bond; positional isomeric effect

\section{Introduction}

Despite its 60-year history, naturally occurring 2-phenyl-benzofuran is not a well-known type of stilbene. In 1958, a new product was discovered in yeast and identified as 2-(6-hydroxy-2-methoxy-3, 4-methylenedioxyphenyl)-benzofuran by Meisinger et al. [1]. Since then, over sixty other 2-phenylbenzofuran derivatives [2] have been successfully isolated from different plants, especially from Morus alba [3,4], Artocarpus champeden [5], Erythrina addisoniae [6], and Calpocalyx dinklagei [7]. Structurally, all these compounds contain a scaffold of 2-phenyl substituted benzo[ $b]$ furan-fused-ring (Figure 1). This scaffold is usually called 2-phenyl-benzofuran, although somestudies also refer to it as "2-arylbenzofuran" or "aryl benzofuran" [6-8]. The latter two terms, however, are ambiguous because aryl can refer to any heterocycle-not specifically the phenyl ring. For example, recently synthesized 2-quinolyl benzofuran derivatives are aryl benzofurans [9], but not phenyl-benzofurans. More importantly, the nomenclature 2-phenyl-benzofuran conforms with the IUPAC rule, and is identical with the 
name of the first isolated natural benzofuran compound [1] and a wide range of similar compounds in the literature [2]. Possibly due to the mess of terminology, some handbooks have not recorded these derivatives as an independent type of natural product. Thus, very few people have recognized natural 2-phenyl-benzofuran derivatives.

Moracin C from Morus alba or Artocarpus heterophyllus is one of the more well-known natural 2-phenyl-benzofuran derivatives [10]. As shown in Figure 2A, moracin C contains three phenolic -OH groups at the 6,3', $5^{\prime}$-positions. Thus, it can also be regarded as a phytophenol [11]. Of course, it is dissimilar to any of the common phytophenols, such as flavonoid [12], flavonoid glucoside [13], biflavonoid [14], volatile phenol [15], phenolic cumarin [16], phenolic alkaloid [17], phenolic acid [18,19], and phenolic acid ester [20]. Like most phytophenols, however, the characteristic phenolic moiety of moracin C makes it of interest to many researchers. Recently, Yao et al. used a cellular model to explore its inhibitory effect on the nitric oxide production of RAW264.7 cells [10]; while Zelová et al. reported its anti-inflammatory activity [21]. In addition, moracin $C$ has also been found to inhibit fatty acid synthesis [22] and lipoxygenase levels [23], both of which are positively correlated with oxidative stress $[24,25]$. These three inhibitory effects of moracin $C$ are thought to originate from an antioxidant action. However, to the best of our knowledge, there is no relevant study to date on the antioxidant action of moracin $\mathrm{C}$.

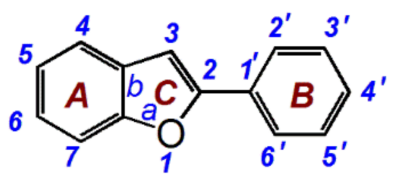

Figure 1. The scaffold of 2-phenyl-benzofurans.

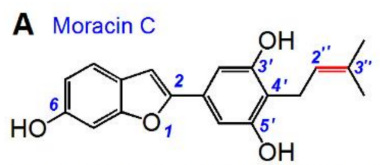

B Iso-moracin C

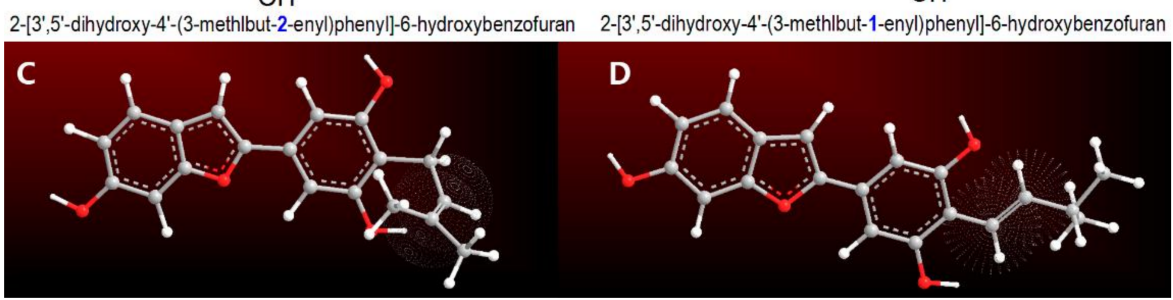

Figure 2. Structures and preferential conformation-based ball-stick models of moracin $\mathrm{C}$ and its isomer: (A) the structure of moracin C; (B) the structure of iso-moracin C; (C) the preferential conformation-based ball-stick model of moracin C; (D) the preferential conformation-based ball-stick model of iso-moracin C. The ball-stick models were created in Chem3D Pro 14.0. The three-dimensional perspective animations are shown in Video S1 and S2.

Notably, an isomer of moracin C (Figure 2B) has also been found in Artocarpus family [8,23]. Similar to moracin $C$, the isomer has been given two nonstandard names. Some published works refer it as artoindonesianin B-1 [8]. This name is readily associated with artoindonesianin B, a flavonoid from Artocarpus champeden (Figure S1) [5]. As seen in Figure S1, however, the flavonoid artoindonesianin B is quite different from the isomer of moracin C (Figure 2B). The supplier also calls this compound 5-(6-hydroxybenzofuran-2-yl)-2-(3-methylbut-1-enyl)benzene-1,3-diol. While this name can be used to deduce its chemical structure, it does not comply with IUPAC terminology; i.e., the numbering does not start from the $\mathrm{O}$-atom of the furan ring. This nomenclature is also different from that of the first reported natural 2-phenyl-benzofuran derivative [i.e., 2-(6-hydroxy-2-methoxy-3,4-methylenedioxy phenyl)-benzofuran] [1] and other analogous derivatives such as 2-[2', $4^{\prime}$-dihydroxy-3'-(3-methlbut- 
2-enyl)phenyl]-6-hydroxybenzofuran, 2-[2'-methoxy-4'-hydroxy-5'-(3-methlbut-2-enyl)phenyl]-6hydroxybenzofuran, and 2-(2'-methoxy-4'-hydroxyphenyl)-5-(3-methlbut-2-enyl)-6-hydroxy benzofuran [2].

In this work, we have re-named the isomer 2-[3',5'-dihydroxy-4'-(3-methlbut-1-enyl)phenyl]-6hydroxybenzofuran, according to the IUPAC rule. For convenience, we also refer to it as iso-moracin C, since it is actually the isomer of moracin C. Correspondingly, we have also assigned the IUPAC name for moracin C: 2-[3',5'-dihydroxy-4'-(3-methlbut-2-enyl)phenyl]-6-hydroxybenzofuran.

As seen in Figure 2, the difference between moracin $C$ and iso-moracin $C$ is only the position of the $\mathrm{C}=\mathrm{C}$ double bond. In moracin $\mathrm{C}$, the double bond is at the $2^{\prime \prime}$-position, whilst in iso-moracin $\mathrm{C}$ the double bond is at the $1^{\prime \prime}$-position. At the $1^{\prime \prime}$-position, the double bond facilitates conjugation with the phenyl group, and further, with the benzofuran-fused-ring. On the other hand, the double bond at the $2^{\prime \prime}$-position cannot conjugate with the phenyl group or the benzofuran fused ring; it remains an isolated functional group. In other words, the difference between the isomers results in different degrees of conjugation. This change is obviously dissimilar to that observed in other isomers such as ferulic acid, isoferulic acid [26], and atractylenolides [27]. Conjugation, in turn, can change the electron distribution within the molecule, significantly affecting the antioxidant properties of the phytophenol [28]. In this work, therefore, we postulate that the double bond positional isomerization between moracin $C$ and iso-moracin $C$ will affect their antioxidant abilities. The present study uses spectrophotometry and HPLC-MS chemical approaches to comparatively explore the antioxidant action of moracin $\mathrm{C}$ and its isomer. Spectrophotometry is used to evaluate the superoxide radical $\left(\bullet \mathrm{O}_{2}{ }^{-}\right)$-inhibition, $\mathrm{Cu}^{2+}$-reducing power, DPPH $\bullet$-inhibition, and $\mathrm{ABTS}^{+} \bullet$-inhibition; while HPLC-MS is used to measure the RAF potential. Our study will help us to understand the antioxidant ability and mechanisms of moracin $C$ and iso-moracin C. More importantly, it will also provide new information about the effect of the double bond position on the antioxidant properties of phytophenols-especially phenolic 2-phenyl-benzofurans.

\section{Results and Discussion}

Excessive reactive oxygen species (ROS) or reactive nitrogen species (RNS) are the source of cellular oxidative stress; decreasing either can effectively relieve the oxidative stress in the cells. The process by which this occurs is commonly called "antioxidation"; essentially, this process consists of reactions which inhibit ROS or RNS accumulation. $\bullet \mathrm{O}_{2}{ }^{-}$is a significant form of ROS. In the present study, it was inhibited by both moracin $\mathrm{C}$ and iso-moracin $\mathrm{C}$ in a dose-dependent manner (Figure S2). Furthermore, both moracin $\mathrm{C}$ and iso-moracin $\mathrm{C}$ displayed higher percentages of $\bullet \mathrm{O}_{2}{ }^{-}$inhibition compared to Trolox, a standard antioxidant. This indicated that both moracin $\mathrm{C}$ and iso-moracin $\mathrm{C}$ are good antioxidants.

ROS and RNS induce cellular oxidative stress and injure biomolecules in cells due to the presence of unpaired electrons in their structures which make them highly unstable. However, as long as the unpaired electron is paired by an external electron donating system, these species can be inactivated and become harmless to cells. As such, electron-transfer (ET) from antioxidants (specifically phenolic antioxidants) to ROS or RNS is proposed as an important antioxidant approach [29], and antioxidants are frequently investigated for their ET potential using chemical approaches.

From the perspective of chemistry, ET is actually a redox reaction. For example, the metal ion $\mathrm{Cu}^{2+}$ can be reduced to $\mathrm{Cu}^{+}$by gaining an electron from another molecule. Accordingly, the $\mathrm{Cu}^{2+}$-reducing capacity assay can experimentally characterize the ET potential of an antioxidant. This assay is called the cupric ion reducing antioxidant capacity (CUPRAC) assay and is carried out under physiological $\mathrm{pH} 7.4$ [30]. In the present study, both moracin $\mathrm{C}$ and iso-moracin $\mathrm{C}$ exhibited relative $\mathrm{Cu}^{2+}$ reducing power which was dependent on the dosage (Figure S3), indicating that both possess the ET potential under physiological conditions.

However, ET from the phenolic moiety is always accompanied by proton $\left(\mathrm{H}^{+}\right)$transfer. A typical application instance is the quinhydrone electrode, which has already been used for determination of 
$\mathrm{pH}$ values in analytical chemistry. The principle of the electrode is the synergism between ET and $\mathrm{H}^{+}$-transfer. Such synergism can also occur in biological systems. For instance, ubiquinone in cellular mitochondria can reversibly accept electron and proton via the hydroquinone form, i.e., ubiquinol with phenolic moiety [31]. Thus, it is postulated that $\mathrm{H}^{+}$-transfer at the phenolic moieties of moracin $\mathrm{C}$ and iso-moracin C may also accompany their ET process. This postulation is supported by the experimental results from the ABTS $\bullet^{+}$-inhibition and DPPH•-inhibition assays. Previous studies suggested that both of these antioxidant assays involve both ET and $\mathrm{H}^{+}$-transfer. Specifically, their antioxidant mechanisms can be described as loss single electron-transfer (SPLET) [12,32], proton coupled electron-transfer (PCET) [33,34], sequential electron $\mathrm{H}^{+}$-transfer (SEPT) [14,33,35], and even hydrogen atom transfer (HAT) $[14,15,36]$. HAT, however can be considered as a process where ET and $\mathrm{H}^{+}$are transferred inseparably. In fact, even the ET-based CUPRAC assay could liberate $\mathrm{H}^{+}$when it is used for phenolic antioxidants [37]; the aforementioned $\bullet \mathrm{O}_{2}{ }^{-}$-inhibition assay by phenolic antioxidants has also recently been reported to comprise ET and $\mathrm{H}^{+}$-transfer [38,39].

In short, as phenolic 2-phenyl-benzofurans, moracin $C$ and iso-moracin $C$ may likely exhibit the antioxidant effect through redox-related mechanisms, which are characterized by ET and $\mathrm{H}^{+}$-transfer. However, as shown in Figure 3, moracin $C$ and iso-moracin $C$ showed significantly different antioxidant levels in $\bullet \mathrm{O}_{2}{ }^{-}$-inhibition, CUPRAC, DPPH•-inhibition, and $\mathrm{ABTS}^{+} \bullet$-inhibition assays. In the four antioxidant assays, iso-moracin $\mathrm{C}$ always gave lower $\mathrm{IC}_{50}$ values than moracin $\mathrm{C}$, implying that iso-moracin $\mathrm{C}$ is more active than moracin $\mathrm{C}$ in the redox-related reactions. Structurally, the sole difference between two isomers is the double bond $(\mathrm{C}=\mathrm{C})$ position. Therefore, their different redox-related antioxidant potentials can only be attributed to the double bond position.

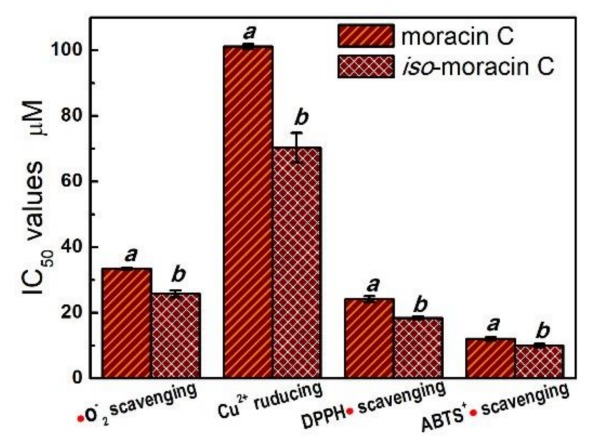

Figure 3. The $\mathrm{IC}_{50}$ values of moracin $\mathrm{C}$ and iso-moracin $\mathrm{C}$ in antioxidant assays, including $\bullet \mathrm{O}_{2}{ }^{-}$ inhibition assay, CUPRAC assay, DPPH•-inhibition assay, and $\mathrm{ABTS}^{+} \bullet$-inhibition assay.

The $\mathrm{IC}_{50}$ value was defined as the final concentration of $50 \%$ radical inhibition or relative reducing power and calculated by linear regression analysis and expressed as the mean $\pm \mathrm{SD}(n=3)$. The linear regression was analyzed by Origin 6.0 professional software. The $\mathrm{IC}_{50}$ value $(\mu \mathrm{g} / \mathrm{mL})$ was converted into $\mu \mathrm{M}$ and collected in brackets. The $\mathrm{IC}_{50}$ value in $\mu \mathrm{M}$ with different superscripts (a or $\mathrm{b}$ ) in the same row are significantly different $(p<0.05)$. The dose-response curves of the positive control Trolox are listed in Figures S2-S5.

As mentioned above, in iso-moracin $C$ molecule, $1^{\prime \prime}-\mathrm{C}=\mathrm{C}$ bond conjugates with the 2-phenyl-benzofuran core to extend the $\pi-\pi$ system. Density functional response theory has indicated that the extended $\pi-\pi$ conjugation has a stronger capacity to stabilize the radical species via delocalization of the $\pi$-electrons [40]. Hence, iso-moracin C molecule, with an extended $\pi-\pi$ conjugation, exhibited stronger redox-related antioxidant potential than moracin $C$. It can be inferred that, if double bond position can extend the $\pi-\pi$ conjugative system, it can correspondently enhance the redox-related antioxidant potential.

It must be emphasized that besides the redox-related pathways, some non-redox reactions may also occur during the antioxidant process. A typical reaction is the radical-adduct-formation (RAF) reaction. In fact, RAF was observed in DPPH•-inhibition [16], $\bullet \mathrm{O}_{2}{ }^{-}$-inhibition [41], and $\mathrm{ABTS}^{+} \bullet-$ 
inhibition can [42]. In order to verify the possibility of the RAF pathway by moracin C and iso-moracin C, each of them was mixed with the DPPH• radical and the reaction products analyzed using HPLC-MS.
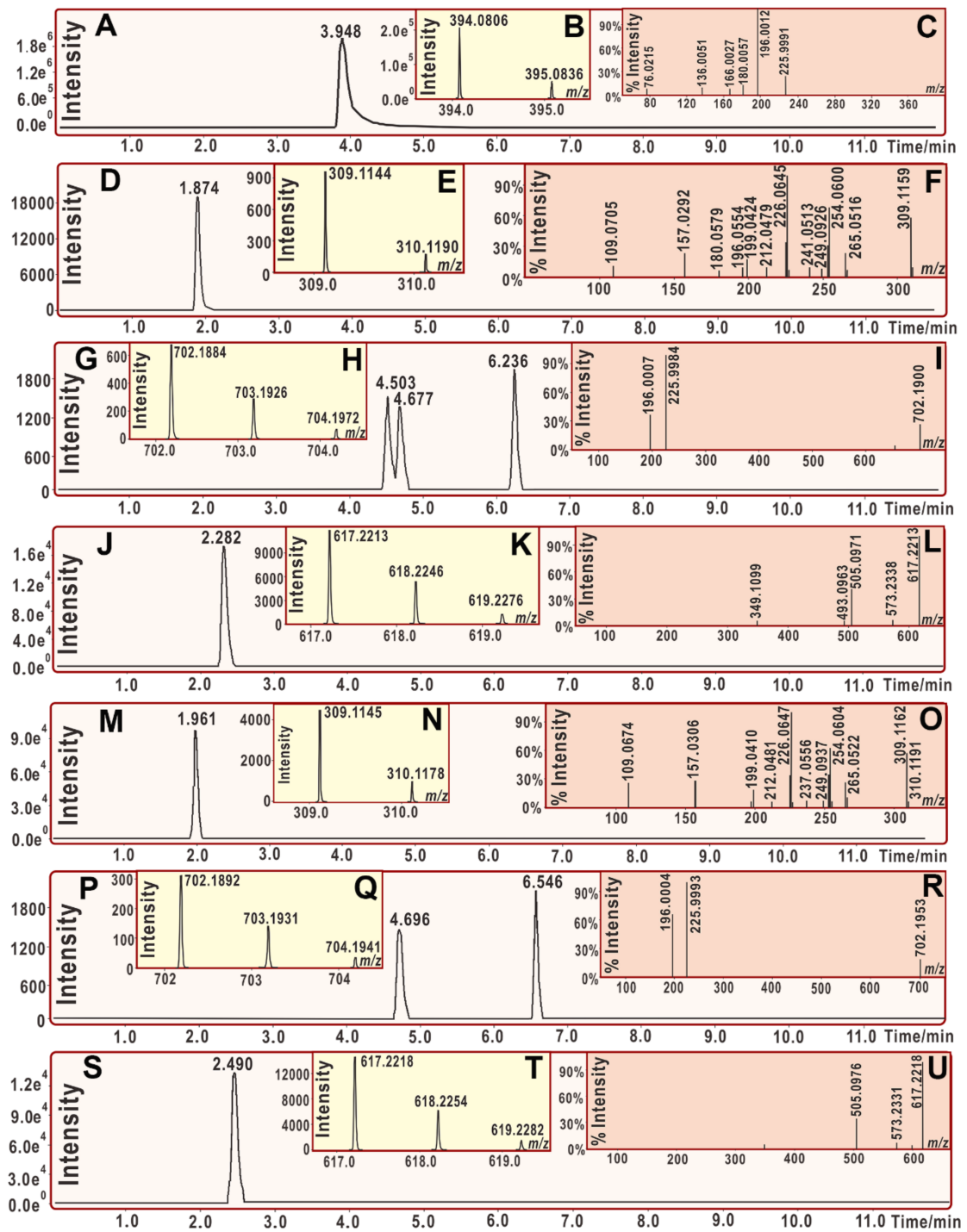

Figure 4. The main results of UPLC-MS analysis:(A, Chromatogram of DPPH• when the formula

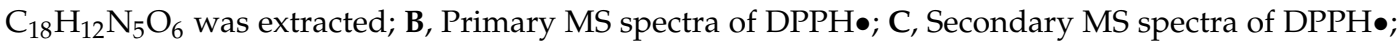
D, Chromatogram of moracin $\mathrm{C}$ when the formula $\left[\mathrm{C}_{19} \mathrm{H}_{18} \mathrm{O}_{4}-\mathrm{H}\right]^{-}$was extracted; E, Primary MS spectra of moracin C; F, Secondary MS spectra of moracin C; G, chromatogram of RAF product of moracin C-DPPH when the formula $\left[\mathrm{C}_{37} \mathrm{H}_{29} \mathrm{~N}_{5} \mathrm{O}_{10}-\mathrm{H}\right]^{-}$was extracted; $\mathbf{H}$, primary MS spectra of RAF product of moracin C-DPPH; I, secondary MS spectra of RAF product of moracin C-DPPH; J, chromatogram of RAF product of moracin C-moracin $\mathrm{C}$ when the formula $\left[\mathrm{C}_{38} \mathrm{H}_{34} \mathrm{O}_{8}-\mathrm{H}\right]^{-}$was extracted; K, primary MS spectra of RAF product of moracin C-moracin C; L, secondary MS spectra of RAF product of moracin C-moracin C; $\mathbf{M}$, Chromatogram of iso-moracin $\mathrm{C}$ when the formula $\left[\mathrm{C}_{19} \mathrm{H}_{18} \mathrm{O}_{4}-\mathrm{H}\right]^{-}$was extracted; $\mathbf{N}$, Primary MS spectra of iso-moracin $\mathrm{C} ; \mathbf{O}$, secondary MS spectra of iso-moracin C; $\mathbf{P}$, chromatogram of RAF product of iso-moracin C-DPPH when the formula $\left[\mathrm{C}_{37} \mathrm{H}_{29} \mathrm{~N}_{5} \mathrm{O}_{10}-\mathrm{H}\right]^{-}$was extracted; $\mathbf{Q}$, primary MS spectra of RAF product of iso-moracin C-DPPH; $\mathbf{R}$, secondary MS spectra of RAF product of iso-moracin C-DPPH; $\mathbf{S}$, chromatogram of RAF product of iso-moracin C-iso-moracin $\mathrm{C}$ when the formula $\left[\mathrm{C}_{38} \mathrm{H}_{34} \mathrm{O}_{8}-\mathrm{H}\right]^{-}$was extracted; $\mathrm{T}$, primary MS spectra of RAF product of iso-moracin C-iso-moracin C; $\mathbf{U}$, secondary MS spectra of RAF product of iso-moracin C-iso-moracin C. 
As seen in Figure 4A-F, DPPH• standard yielded molecular ion peaks $(m / z$ 394-394), and two fragments $(m / z 196$ and 226); while moracin $C$ standard produced molecular ion peaks $(m / z$ 309-310). The product mixture of moracin $C$ with DPPH• gave molecular ion peaks $(m / z 702-703)$ (Figure $4 \mathrm{G}-\mathrm{H}$ ). The RAF product moracin C-DPPH might be further broken to give $m / z 196$ and 226 fragments (Figure 4I). The molecular ion peaks $(m / z$ 702-703) and fragment peaks $(m / z 196$ and 226) strongly indicated a RAF product moracin C-DPPH. In addition, the product mixture of moracin $C$ with DPPH• also gave the peaks of $m / z$ 617-618 (Figure $4 \mathrm{~K}$ ). These are regarded as the dimeric moracin C-moracin C. Now it is clear that, when mixed with DPPH•, moracin $\mathrm{C}$ can bring about two RAF products, i.e., moracin C-DPPH and moracin C-moracin C.

Similarly, iso-moracin C also produced MS peaks at $m / z$ 702-703 and $m / z$ 617-618 (Figure 4Q,T), indicating the generation of iso-moracin $\mathrm{C}-\mathrm{DPPH}$ and dimeric iso-moracin C-iso-moracin $\mathrm{C}$. Further analysis revealed that the secondary MS spectra of iso-moracin C-DPPH highly resembled those of moracin C-DPPH (Figure 4I,R). It can be deduced that, DPPH moiety linked to the ring scaffold not side-chain. This is because if DPPH moiety linked to the side-chain containing $\mathrm{C}=\mathrm{C}$, the different positions of $\mathrm{C}=\mathrm{C}$ should cause different $\mathrm{MS}$ fragments between moracin C-DPPH and iso-moracin C-DPPH. On the other hand, the similarity between moracin C-DPPH and iso-moracin C-DPPH further indicated that, the aforementioned double bond $(C=C)$ position had actually no effect towards RAF products.

In a word, both moracin $C$ and iso-moracin $C$ may similarly exert their antioxidant action via a RAF pathway. Through the RAF pathway, they can be transformed into stable dimers or adducts with radical-containing reactants. The $\mathrm{C}=\mathrm{C}$ position is thought to have negligible effect on the RAF pathway.

\section{Materials and Methods}

\subsection{Chemicals}

Moracin C (CAS 69120-06-5, $\mathrm{C}_{19} \mathrm{H}_{18} \mathrm{O}_{4}$, M.W. 310.4, purity 97\%, faint yellow, Figure S6) and iso-moracin C (CAS936006-11-0, $\mathrm{C}_{19} \mathrm{H}_{18} \mathrm{O}_{4}$, M.W. 310.4, purity 97\%, yellow, Figure S6) were obtained from BioBioPha Co., Ltd. (Kunming, China). 1,1-Diphenyl-2-picryl-hydrazyl radical (DPPH•), ( \pm )-6-hydroxyl-2,5,7,8-tetramethylchromane-2-carboxylic acid (Trolox), pyrogallol, and 2,9-dimethyl-1, 10-phenanthroline (neocuproine) were purchased from Sigma-Aldrich Shanghai Trading Co. (Shanghai, China). ( $\mathrm{NH}_{4}$ )2ABTS [2,2'-azino-bis(3-ethylbenzo-thiazoline-6-sulfonic acid diammonium salt)] was obtained from Amresco Chemical Co. (Solon, OH, USA). Acetonitrile was of HPLC grade and formic acid was of LC-MS grade. Other reagents were of analytical grade.

\subsection{Superoxide Anion $\left(\bullet \mathrm{O}_{2}^{-}\right)$Inhibiting Assay (Spectrophotometry)}

Superoxide anion $\left(\bullet \mathrm{O}_{2}{ }^{-}\right)$inhibiting activity was measured using a pyrogallol autooxidation method that was previously improved in our laboratory [43]. Briefly, the sample was dissolved in methanol at $1 \mathrm{mg} / \mathrm{mL}$. The sample solution $(x=2-10 \mu \mathrm{L})$ was mixed with Tris- $\mathrm{HCl}$ buffer $(980-x \mu \mathrm{L}$, $0.05 \mathrm{M}, \mathrm{pH} 7.4)$ containing EDTA $(1 \mathrm{mM})$. After $20 \mu \mathrm{L}$ pyrogallol $(60 \mathrm{mM}$ in $1 \mathrm{mM} \mathrm{HCl})$ was added, the mixture was vigorously shaken at room temperature. The absorbance of the mixture was measured (Unico 2100, Shanghai, China) at $325 \mathrm{~nm}$ every $30 \mathrm{~s}$ for $5 \mathrm{~min}$. Tris- $\mathrm{HCl}$ buffer was used as a blank. The $\bullet \mathrm{O}_{2}{ }^{-}$inhibiting ability was calculated as follows:

$$
\text { Inhibition } \%=\frac{\left(\frac{\Delta \mathrm{A}_{325 \mathrm{~nm}, \text { control }}}{\mathrm{T}}\right)-\left(\frac{\Delta \mathrm{A}_{325 \mathrm{~nm}, \text { control }}}{\mathrm{T}}\right)}{\left(\frac{\Delta \mathrm{A}_{325 n \mathrm{~nm}, \text { control }}}{\mathrm{T}}\right)} \times 100 \%
$$

Here, $\Delta \mathrm{A}_{325 \mathrm{~nm} / \mathrm{control}}$ is the increment in the absorbance at $325 \mathrm{~nm}\left(\mathrm{~A}_{325 \mathrm{~nm}}\right)$ of the mixture without

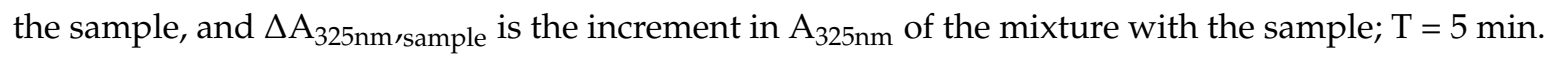




\subsection{CUPRAC Assay (Spectrophotometry)}

Cupric ion reducing antioxidant capacity (CUPRAC) assay was determined based on the method proposed by Apak et al. [44], with small modifications as presented in the literature of Jiang [45]. Twelve $\mu \mathrm{L} \mathrm{CuSO}_{4}$ solution $(0.01 \mathrm{M})$ and $12 \mu \mathrm{L}$ ethanolic neocuproine solution $\left(7.5 \times 10^{-3} \mathrm{M}\right)$ were added to a 96-well and mixed with different concentrations of samples $(10-50 \mu \mathrm{g} / \mathrm{mL})$. The total volume was then adjusted to $100 \mu \mathrm{L}$ with a $\mathrm{CH}_{3} \mathrm{COONH}_{4}$ buffer solution $(0.1 \mathrm{M})$, and mixed again to homogenize the solution. The mixture was maintained at room temperature for $30 \mathrm{~min}$, and the absorbance was measured at $450 \mathrm{~nm}$ on a microplate reader (Multiskan FC, Thermo Scientific, Shanghai, China). The relative reducing power of the sample was calculated using the formula:

$$
\text { Relative reducing effect } \%=\frac{A-A_{\min }}{A_{\max }-A_{\min }} \times 100 \%
$$

where $A$ is the absorbance of sample at $450 \mathrm{~nm}, A_{\max }$ is the maximum absorbance at $450 \mathrm{~nm}$, and $A_{\text {min }}$ is the minimum absorbance in the test at $450 \mathrm{~nm}$.

\subsection{DPPH•-Scavenging and ABTS $\bullet^{+}$-Scavenging Assays (Spectrophotometry)}

$\mathrm{DPPH} \bullet$ radical scavenging activity was determined as previously described [46]. Briefly, $80 \mu \mathrm{L}$ of $\mathrm{DPPH} \bullet$ solution $(0.1 \mathrm{~mol} / \mathrm{L})$ was mixed with methanolic sample solutions having the indicated concentration $(0.125 \mathrm{mg} / \mathrm{mL}, 1-5 \mu \mathrm{L})$. The mixture was maintained at room temperature for $30 \mathrm{~min}$, and the absorbance was measured at $519 \mathrm{~nm}$ on a microplate reader. The percentage of DPPH• scavenging activity was calculated using the following equation:

$$
\text { Scavenging } \%=\frac{A_{0}-A}{A_{0}} \times 100 \%
$$

where $A_{0}$ indicates the absorbance of the blank at the specified wavelength and $A$ indicates the absorbance of the sample at the specified wavelength.

The ABTS $\bullet^{+}$- scavenging activity was evaluated according to the method described by Wang et al. [47]. The ABTS $\bullet^{+}$was produced by mixing $0.2 \mathrm{~mL}$ of $\left(\mathrm{NH}_{4}\right)_{2} \mathrm{ABTS}(7.4 \mathrm{mmol} / \mathrm{L})$ with $0.35 \mathrm{~mL}$ of potassium persulfate $(2.6 \mathrm{mmol} / \mathrm{L})$. The mixture was kept in the dark at room temperature for $12 \mathrm{~h}$ to allow completion of radical generation, and then diluted with distilled water ( 1:20), such that its absorbance at $734 \mathrm{~nm}$ was measured on a microplate reader. To determine the scavenging activity, the test sample $(x=1-5 \mu \mathrm{L}, 0.125 \mathrm{mg} / \mathrm{mL})$ was added to $(20-x) \mu \mathrm{L}$ of distilled water followed by $80 \mu \mathrm{L}$ of $\mathrm{ABTS}^{+}{ }^{+}$reagent, and the absorbance at $734 \mathrm{~nm}$ was measured $3 \mathrm{~min}$ after the initial mixing, using distilled water as the blank. The percentage inhibition of the samples was calculated based on the equation governing DPPH• scavenging.

\subsection{Determining DPPH• Reaction Products with Moracin C or Iso-Moracin C (UPLC-ESI-Q-TOF-MS/MS Analysis)}

The reaction conditions were based on the maclurin experiment [33]. In brief, a methanolic solution of moracin $C$ was mixed with a methanolic solution of DPPH• at a molar ratio of 1:2, and the resulting mixture was incubated for $5 \mathrm{~h}$ at room temperature. The product was then filtered through a 0.22- $\mu \mathrm{m}$ filter for UPLC-ESI-Q-TOF-MS/MS analysis.

The UPLC-ESI-Q-TOF-MS/MS analysis was based on our reported method [48]. The UPLC-ESI-QTOF-MS/MS analysis system was equipped with a $\mathrm{C}_{18}$ column $(2.0 \mathrm{~mm}$ i.d. $\times 100 \mathrm{~mm}, 2.2 \mu \mathrm{m}$, Shimadzu Co., Kyoto, Japan). The mobile phase used for the elution of the system consisted of a mixture of acetonitrile (phase A) and $0.1 \%$ aqueous formic acid (phase B). The column was eluted at a flow rate of $0.2 \mathrm{~mL} / \mathrm{min}$ with the following gradient elution program: $0-2 \mathrm{~min}$, maintain $30 \% \mathrm{~B}$; $2-10 \mathrm{~min}, 30-0 \% \mathrm{~B} ; 10-12 \mathrm{~min}, 0-30 \% \mathrm{~B}$. The sample injection volume was set at $1 \mu \mathrm{L}$ for the separation of the different components, column temperature was $40^{\circ} \mathrm{C}$. Q-TOF-MS/MS analysis was performed 
on a Triple TOF 5600 plus Mass spectrometer (AB SCIEX, Framingham, MA, USA) equipped with an ESI source, which was run in the negative ionization mode. The scan range was set at 100-2000 Da. The system was run with the following parameters: ion spray voltage, $-4500 \mathrm{~V}$; ion source heater, $550{ }^{\circ} \mathrm{C}$; curtain gas (CUR, $\mathrm{N}_{2}$ ), 30 psi; nebulizing gas (GS1, Air), $50 \mathrm{psi}$; Tis gas (GS2, Air), 50 psi. The declustering potential (DP) was set at $-100 \mathrm{~V}$, whereas the collision energy (CE) was set at $-40 \mathrm{~V}$ with a collision energy spread (CES) of $20 \mathrm{~V}$. The RAF products were quantified by extracting the corresponding ion formula (e.g., $\left[\mathrm{C}_{37} \mathrm{H}_{29} \mathrm{~N}_{5} \mathrm{O}_{10}-\mathrm{H}\right]^{-}$for moracin C-DPPH•) from the total ion chromatogram and integrating the corresponding peak.

\subsection{Statistical Analysis}

Each experiment was performed in triplicate and the data were recorded as mean $\pm \mathrm{SD}$ (standard deviation). The dose-response curves were plotted using Origin 6.0 professional software (OriginLab, Northampton, MA, USA). The $\mathrm{IC}_{50}$ value was defined as the final concentration of $50 \%$ radical inhibition (or relative reducing power). It was calculated by linear regression analysis, and expressed as the mean $\pm \mathrm{SD}(n=3)$. The linear regression was analyzed using Origin 6.0. Determination of significant differences between the mean $\mathrm{IC}_{50}$ values was performed using one-way ANOVA and the $t$-test. The analysis was performed using SPSS software 13.0 (SPSS Inc., Chicago, IL, USA) for windows. $p<0.05$ was considered to be statistically significant.

\section{Conclusions}

Both moracin C and iso-moracin C can inhibit ROS, likely through redox-related pathways (specially ET and $\mathrm{H}^{+}$-transfer) and a non-redox-related RAF pathway. In the redox-related pathways, a double bond at the conjugation position can enhance the ET and $\mathrm{H}^{+}$-transfer potential. However, in the non-redox-related pathway, the double bond position hardly affected the RAF potential.

Supplementary Materials: The following supplementary materials are available online. Video S1 and S2: Animations of moracin C and iso-moracin C; Figure S1: Structure of artoindonesianin B; Figure S2-S5: Dose response curves; Figure S6: Photos of moracin C and iso-moracin C.

Acknowledgments: This work was supported by the National Nature Science Foundation of China (81573558), Natural Science Foundation of Guangdong Province (2017A030312009), and Guangdong Science and Technology Project (2017A050506043).

Author Contributions: Xican Li and Dongfeng Chen conceived and designed the experiments; Hong Xie and Ruicai Zhan performed the antioxidant experiments; Hong Xie analyzed the experimental data; Xican Li wrote the paper. All authors read and approved the final manuscript.

Conflicts of Interest: The authors declare that they have no competing interests.

\section{Abbreviations}

The following abbreviations are used in this manuscript:

$\begin{array}{ll}\text { ABTS } & \text { 2,2'-azino-bis (3-ethylbenzo-thiazoline-6-sulfonic acid) diammonium salt } \\ \text { DPPH• } & \text { 1,1-diphenyl-2-picryl-hydrazl } \\ \text { ET } & \text { electron-transfer } \\ \text { FBS } & \text { fetal bovine serum } \\ \text { FRAP } & \text { ferric reducing antioxidant power } \\ \text { HAT } & \text { hydrogen atom transfer } \\ \text { ROS } & \text { reactive oxygen species } \\ \text { RAF } & \text { radical-adduct-formation } \\ \text { SD } & \text { standard deviation } \\ \text { TPTZ } & \text { 2,4,6-tris(2-pyridyl-s-triazine) } \\ \text { Trolox } & ( \pm) \text {-6-hydroxyl-2,5,7,8-tetramethlychromane-2-carboxylic acid }\end{array}$




\section{References}

1. Meisinger, M.A.P.; Kuehl, F.A., Jr.; Rickes, E.L.; Brink, N.G.; Folkers, K.; Forbes, M.; Zilliken, F.; Gyorgy, P. The Structure of a New Product from Yeast: 2-(6-Hydroxy-2-methoxy-3,4-methylenedioxyphenyl)-benzofuran. J. Am. Chem. Soc 1959, 81, 4979-4982. [CrossRef]

2. Qin, H.L.; Yu, D.O. ${ }^{1}$ H-NMR Spectroscopic Databook of Natural Products, 1st ed.; Chemical Industry Press: Beijing, China, 2011; pp. 2224-2235.

3. Pel, P.; Chae, H.S.; Nhoek, P.; Kim, Y.M.; Chin, Y.W. Chemical Constituents with Proprotein Convertase Subtilisin/Kexin Type 9 mRNA Expression Inhibitory Activity from Dried Immature Morus alba Fruits. J. Agric. Food Chem. 2017, 65, 5316-5321. [CrossRef] [PubMed]

4. Naik, R.; Harmalkar, D.S.; Xu, X.; Jang, K.; Lee, K. Bioactive benzofuran derivatives: Moracins A-Z in medicinal chemistry. Eur. J. Med. Chem. 2015, 90, 379-393. [CrossRef] [PubMed]

5. Hakim, E.H.; Fahriyati, A.; Kau, M.S.; Achmad, S.A.; Makmur, L.; Ghisalberti, E.L.; Nomura, T. Artoindonesianins A and B, two new prenylated flavones from the root of Artocarpus champeden. J. Nat. Prod. 1999, 62, $613-615$. [CrossRef] [PubMed]

6. Na, M.; Hoang, D.M.; Njamen, D.; Mbafor, J.T.; Fomum, Z.T.; Thuong, P.T.; Ahn, J.S.; Oh, W.K. Inhibitory effect of 2-arylbenzofurans from Erythrina addisoniae on protein tyrosine phosphatase-1B. Bioorg. Med. Chem. Lett. 2007, 17, 3868-3871. [CrossRef] [PubMed]

7. Kapche, D.; Lekane, N.M.; Kulabas, S.S.; Ipek, H.; Tok, T.T.; Ngadjui, B.T.; Demirtas, I.; Tumer, T.B. Aryl benzofuran derivatives from the stem bark of Calpocalyx dinklagei attenuate inflammation. Phytochemistry 2017, 141, 70-79. [CrossRef] [PubMed]

8. Wu, D.; Mei, H.; Tan, P.; Lu, W.; Zhu, J.; Wang, W.; Huang, J.; Li, J. Total synthesis of the 2-arylbenzo[b]furancontaining natural products from Artocarpus. Tetrahedron Lett. 2015, 56, 4383-4387. [CrossRef]

9. Chand, K.; Rajeshwari; Hiremathad, A.; Singh, M.; Santos, M.A.; Keri, R.S. A review on antioxidant potential of bioactive heterocycle benzofuran: Natural and synthetic derivatives. Pharmacol. Rep 2017, 69, $281-295$. [CrossRef] [PubMed]

10. Yao, X.; Wu, D.; Dong, N.; Ouyang, P.; Pu, J.; Hu, Q.; Wang, J.; Lu, W.; Huang, J.; Moracin, C. A Phenolic Compound Isolated from Artocarpus heterophyllus, Suppresses Lipopolysaccharide-Activated Inflammatory Responses in Murine Raw264.7 Macrophages. Int. J. Mol. Sci. 2016, 17, 1199. [CrossRef] [PubMed]

11. Li, X.; Chen, D.; Mai, Y.; Wen, B.; Wang, X. Concordance between antioxidant activities in vitro and chemical components of Radix astragali (Huangqi). Nat. Prod. Res. 2012, 26, 1050-1053. [CrossRef] [PubMed]

12. Li, X.; Liu, J.; Lin, J.; Wang, T.; Huang, J.; Lin, Y.; Chen, D. Protective Effects of Dihydromyricetin against •OH-Induced Mesenchymal Stem Cells Damage and Mechanistic Chemistry. Molecules 2016, $21,604$. [CrossRef] [PubMed]

13. Li, X.; Mai, W.Q.; Chen, D.F. Chemical study on protective effect against hydroxyl-induced DNA damage and antioxidant mechanism of myricitrin. J. Chin. Chem. Soc. 2014, 61, 383-391. [CrossRef]

14. Li, X.; Han, W.; Mai, W.Q.; Wang, L. Antioxidant activity and mechanism of Tetrahydroamentoflavone in vitro. Nat. Prod. Commun. 2013, 8, 787-789.

15. Lin, J.; Li, X.; Chen, L.; Lu, W.; Chen, X.; Han, L.; Chen, D. Protective effect against hydroxyl radical-induced DNA damage and antioxidant mechanism of [6]-gingerol: A Chemical Study. Bull. Korean Chem. Soc. 2014, 35, 1633-1638. [CrossRef]

16. Li, X.; Wang, T.; Liu, J.; Liu, Y.; Zhang, J.; Lin, J.; Zhao, Z.; Chen, D. Effect and mechanism of wedelolactone as antioxidant-coumestan on $\bullet \mathrm{OH}$-treated mesenchymal stem cells. Arab. J. Chem. 2017. [CrossRef]

17. Li, X.; Han, L.; Li, Y.; Zhang, J.; Chen, J.; Lu, W.; Zhao, X.; Lai, Y.; Chen, D.; Wei, G. Protective Effect of Sinapine against Hydroxyl Radical-Induced Damage to Mesenchymal Stem Cells and Possible Mechanisms. Chem. Pharm. Bull. (Tokyo) 2016, 64, 319-325. [CrossRef] [PubMed]

18. Li, X.; Wu, X.; Huang, L. Correlation between Antioxidant Activities and Phenolic Contents of Radix Angelicae sinensis (Danggui). Molecules 2009, 14, 5349-5361. [CrossRef] [PubMed]

19. Chen, D.F.; Li, X.; Xu, Z.; Liu, X.; Du, S.H.; Li, H.; Zhou, J.H.; Zeng, H.P.; Hua, Z.C. Hexadecanoic acid from Buzhong Yiqi decoction induced proliferation of bone marrow mesenchymal stem cells. J. Med. Food. 2010, 13, 967-970. [CrossRef] [PubMed] 
20. Li, X.C.; Hu, Q.P.; Jiang, S.X.; Li, F.; Lin, J.; Han, L.; Hong, Y.L.; Lu, W.B.; Gao, Y.X.; Chen, D.F. Flos Chrysanthemi Indici protects against hydroxyl-induced damages to DNA and MSCs via antioxidant mechanism. J. Saudi Chem. Soc. 2015, 19, 454-460. [CrossRef]

21. Zelová, H.; Hanáková, Z.; Čermáková, Z.; Šmejkal, K.; Dall, A.S.; Babula, P.; Cvačka§, J.; Hošek, J. Evaluation of Anti-Inflammatory Activity of Prenylated Substances Isolated from Morus alba and Morus nigra. J. Nat. Prod. 2014, 77, 1297-1303. [CrossRef] [PubMed]

22. Kim, Y.J.; Sohn, M.J.; Kim, W.G. Chalcomoracin and moracin C, new inhibitors of Staphylococcus aureus enoyl-acyl carrier protein reductase from Morus alba. Biol. Pharm. Bull. 2012, 35, 791. [CrossRef] [PubMed]

23. Lang, L.; Dong, N.N.; Wu, D.Y.; Yao, X.; Lu, W.Q.; Zhang, C.; Ouyang, P.; Zhu, J.; Tang, Y.; Wang, W.; et al. 2-Arylbenzo[b]furan derivatives as potent human lipoxygenase inhibitors. J. Enzyme Inhib. Med. Chem. 2016, 31, 98-105. [CrossRef] [PubMed]

24. Li, X.C.; Jiang, Q.; Wang, T.T.; Liu, J.J.; Chen, D.F. Comparison of the Antioxidant Effects of Quercitrin and Isoquercitrin: Understanding the Role of the 6"-OH Group. Molecules 2016, 21, 1246. [CrossRef] [PubMed]

25. Tersey, S.A.; Maier, B.; Nishiki, Y.; Maganti, A.V.; Nadler, J.L.; Mirmira, R.G. 12-lipoxygenase promotes obesity-induced oxidative stress in pancreatic islets. Mol. Cell Biol. 2014, 34, 3735-3745. [CrossRef] [PubMed]

26. Wang, X.; Li, X.; Chen, D. Evaluation of antioxidant activity of isoferulic acid in vitro. Nat. Prod. Commun. 2011, 6, 1285-1288. [PubMed]

27. Li, X.C.; Wei, G.; Wang, X.Z.; Liu, D.H.; Deng, R.D.; Li, H.; Zhou, J.H.; Li, Y.W.; Zeng, H.P.; Chen, D.F. Targeting of the Shh pathway by atractylenolides promotes chondrogenic differentiation of mesenchymal stem cells. Biol. Pharm. Bull. 2012, 35, 1328-1335. [CrossRef] [PubMed]

28. Mosquera, R.A.; Estevez, L.; Bugarin, M.G. Computational studies on conformation, electron density distributions, and antioxidant properties of anthocyanidins. Methods Mol. Biol. 2015, 1208, 257-276. [PubMed]

29. Sedlak, E.; Musatov, A. Inner mechanism of protection of mitochondrial electron-transfer proteins against oxidative damage. Focus on hydrogen peroxide decomposition. Biochimie 2017, 142, 152-157. [PubMed]

30. Cekic, S.D.; Baskan, K.S.; Tutem, E.; Apak, R. Modified cupric reducing antioxidant capacity (CUPRAC) assay for measuring the antioxidant capacities of thiol-containing proteins in admixture with polyphenols. Talanta 2009, 79, 344-351. [CrossRef] [PubMed]

31. Solomons, T.W.G; Fryhle, B.C. Organic Chemistry, 8th ed.; Chemical Industry Press: Beijing, China, 2004; pp. 1015-1016.

32. Chen, Y.; Xiao, H.; Zheng, J.; Liang, G. Structure-thermodynamics-antioxidant activity relationships of selected natural phenolic acids and derivatives: An experimental and theoretical evaluation. PLoS ONE 2015, 10, e0121276. [CrossRef] [PubMed]

33. Li, X.C.; Gao, Y.; Li, F.; Liang, A.; Xu, Z.; Bai, Y.; Mai, W.; Han, L.; Chen, D. Maclurin protects against hydroxyl radical-induced damages to mesenchymal stem cells: Antioxidant evaluation and mechanistic insight. Chem. Biol. Interact. 2014, 219, 221-228. [CrossRef] [PubMed]

34. Sotiriou, G.A.; Blattmann, C.O.; Deligiannakis, Y. Nanoantioxidant-driven plasmon enhanced proton-coupled electron transfer. Nanoscale 2016, 8, 796-803. [CrossRef] [PubMed]

35. Munoz-Rugeles, L.; Alvarez-Idaboy, J.R. A proton-electron sequential transfer mechanism: Theoretical evidence about its biological relevance. Phys. Chem. Chem. Phys. 2015, 17, 28525-28528. [CrossRef] [PubMed]

36. Apak, R.; Ozyurek, M.; Guclu, K.; Capanoglu, E. Antioxidant Activity/Capacity Measurement. 1. Classification, Physicochemical Principles, Mechanisms, and Electron Transfer (ET)-Based Assays. J. Agric. Food Chem. 2016, 64, 997-1027. [CrossRef] [PubMed]

37. Apak, R.; Güçlü, K.; Demirata, B.; Ozyürek, M.; Celik, S.E.; Bektaşoğlu, B.; Berker, K.I.; Ozyurt, D. Comparative evaluation of various total antioxidant capacity assays applied to phenolic compounds with the CUPRAC assay. Molecules 2007, 12, 1496. [CrossRef] [PubMed]

38. Nakayama, T.; Uno, B. Importance of Proton-Coupled Electron Transfer from Natural Phenolic Compounds in Superoxide Scavenging. Chem. Pharm. Bull. (Tokyo) 2015, 63, 967-973. [CrossRef] [PubMed]

39. Quintero-Saumeth, J.; Rincon, D.A.; Doerr, M.; Daza, M.C. Concerted double proton-transfer electron-transfer between catechol and superoxide radical anion. Phys. Chem. Chem. Phys. 2017, 19, 26179-26190. [CrossRef] [PubMed]

40. Mazzone, G.; Malaj, N.; Russo, N.; Toscano, M. Density functional study of the antioxidant activity of some recently synthesized resveratrol analogues. Food Chem. 2013, 141, 2017-2024. [CrossRef] [PubMed] 
41. Hassan, I.; Pinto, S.; Weisbecker, C.; Attygalle, A.B. Competitive Deprotonation and Superoxide $\left(\bullet \mathrm{O}_{2}{ }^{-}\right)$ Radical-Anion Adduct Formation Reactions of Carboxamides under Negative-Ion Atmospheric-Pressure Helium-Plasma Ionization (HePI) Conditions. J. Am. Soc. Mass Spectrom. 2016, 27, 394-401. [CrossRef] [PubMed]

42. Liu, Y.R.; Li, W.G.; Chen, L.F.; Xiao, B.K.; Yang, J.Y.; Yang, L.; Zhang, C.G.; Huang, R.Q.; Dong, J.X. ABTS•+ scavenging potency of selected flavonols from Hypericum perforatum L. by HPLC-ESI/MS QQQ: Reaction observation, adduct characterization and scavenging activity determination. Food Res. Int. 2014, 58, 47-58. [CrossRef]

43. Li, X. Improved pyrogallol autoxidation method: A reliable and cheap superoxide-scavenging assay suitable for all antioxidants. J. Agric. Food Chem. 2012, 60, 6418-6424. [CrossRef] [PubMed]

44. Apak, R.; Guclu, K.; Ozyurek, M.; Bektas Oglu, B.; Bener, M. Cupric ion reducing antioxidant capacity assay for food antioxidants: Vitamins, polyphenolics, and flavonoids in food extracts. Methods Mol. Biol. 2008, 477, 163-193. [PubMed]

45. Jiang, Q.; Li, X.; Tian, Y.; Lin, Q.; Xie, H.; Lu, W.; Chi, Y.; Chen, D. Lyophilized aqueous extracts of Mori Fructus and Mori Ramulus protect Mesenchymal stem cells from $\bullet \mathrm{OH}$-treated damage: Bioassay and antioxidant mechanism. BMC Complement. Altern. Med. 2017, 16, 423. [CrossRef] [PubMed]

46. Wang, G.; Li, X.; Zeng, H. Synthesis, antioxidation activity of (E)-9-p-Tolyl-3-[2-(8-hydroxy-quinol2-yl)vinyl]-carbazole and (E)-9-(p-Anisyl)-3-[2-(8-hydroxy-quinol-2-yl)vinyl]-carbazole and their induction proliferation of mesenchymal stem cells. Acta Chim. Sin. 2009, 67, 974-982.

47. Wang, T.T.; Zeng, G.C.; Li, X.C.; Zeng, H.P. In vitro studies on the antioxidant and protective effect of 2-substituted-8-hydroxyquinoline derivatives against $\mathrm{H}_{2} \mathrm{O}_{2}$-induced oxidative stress in BMSCs. Chem. Biol. Drug Des. 2010, 75, 214-222. [CrossRef] [PubMed]

48. Li, X. 2-Phenyl-4,4,5,5-tetramethylimidazoline-1-oxyl 3-Oxide (PTIO•) Radical Scavenging: A New and Simple Antioxidant Assay In Vitro. J. Agric. Food Chem. 2017, 65, 6288-6297. [CrossRef] [PubMed]

(C) 2018 by the authors. Licensee MDPI, Basel, Switzerland. This article is an open access article distributed under the terms and conditions of the Creative Commons Attribution (CC BY) license (http:/ / creativecommons.org/licenses/by/4.0/). 